\title{
REVIEW OF SOFTWARE APPLICATIONS FOR AGRICULTURAL PRODUCTION IN CROATIA
}

\author{
PREGLED SOFTVERSKIH APLIKACIJA ZA POLJOPRIVREDNU \\ PROIZVODNJU U HRVATSKOJ
}

\author{
L. Brezinščak, M. Mesić
}

\begin{abstract}
The application of mobile devices (smartphones, tablets, etc.) to the agriculture sector has been greatly increased in the last decade. The ICT technologies have become an essential part of any business. Using Internet on mobile devices can prove to be essential in agriculture production. A new generation of mobile devices are lower in price and more user-friendly. This paper provides an overview of software applications that are created in Croatia and are mostly in the Croatian language. They are divided into groups of agriculture related applications; agriculture management information apps; agriculture information resource apps; agriculture calculator apps; agriculture news apps, weather apps. The research shows the agri-apps are still in its infancy and we can say that it reflects the state of agriculture in Croatia. Apps are a promising solution for farmers enabling them quick and trustworthy access to information. At the moment, further analyses are needed for scientific proof and improvement of a product.
\end{abstract}

Keywords: agricultural production in Croatia, mobile devices, software application

\section{SAŽETAK}

Primjena mobilnih uređaja (smartphona, tableta, itd.) $\mathrm{u}$ sektoru poljoprivrede se uvelike povećala u posljednjih deset godina. Informacijskokomunikacijske tehnologije (ICT) su postale važan dio u svakom poslu. Korištenje Interneta na mobilnim uređajima može se pokazati kao ključno u donošenju odluka u poljoprivrednoj proizvodnji. Nova generacija mobilnih uređaja postiže niže cijene i više je "user-friendly". U radu se daje pregled softverskih aplikacija na hrvatskom jeziku načinjenih u Hrvatskoj. One su podijeljene u skupine poljoprivrednih aplikacija; aplikacije za upravljanje 
Brezinščak, L. i sur.: Review of software applications for agricultural production in Croatia

poljoprivrednom proizvodnjom; aplikacije za dokumentiranje u poljoprivredi; aplikacije za poljoprivredne kalkulacije; vijesti iz poljoprivrede; vremenske prognoze; informacije iz državnih poljoprivrednih institucija. Istraživanje pokazuje da su poljoprivredne aplikacije još uvijek u povojima i možemo reći da one odražavaju stanje poljoprivrede u Hrvatskoj. Aplikacije su obećavajuće rješenje za poljoprivrednike omogućujući im brz i pouzdan pristup informacijama. U ovom trenutku, potrebne su daljnje analize kako bi se znanstveno dokazala pouzdanost dostupnih aplikacija.

Ključne riječi: mobilne aplikacije, mobilni uređaji, poljoprivredna proizvodnja u Hrvatskoj

\section{INTRODUCTION}

Due to the inevitable rise of population, there is an increasing demand for food, both in quantity and quality. For resource optimization in increasing agricultural production use of different technologies and innovation is needed. Personal computers enabled a massive flow of information, but also the management of technology and production processes. Unlike other media, the Internet combines services providing information and possibility of simple twoway communication between people (Efken, 1998.). Which is an excellent characteristic of the Internet for accumulating knowledge, learning new skills and exchanging valuable experience, but also in achieving commercial gain. Mobile communications technology has become the world's most common way of transmitting voice, data, and services (Qiang et al., 2011.). The number of regular Internet users in Croatia is 2197 244, of which 60\% have a secondary education (DZS, 2015.). The structure of the rural population by level of school education is unfavorable and lags behind the educational level of the general population (Ljubaj et al., 2012.), accompanied by higher age, low information literacy and low interest in acceptance of new technologies, a well-known problem as described by Šundalić et al. (2010.). This has influenced the slow progress of wireless and modern methods used in Croatian agriculture. There are currently 441566 cellular subscriptions in Croatia (worldbank.org). Entire lives of generations of people have been influenced by these devices, small in size, low in weight, affordable providing convenience and portability (Fuentelsalz et al., 2008.). Smartphones, newest generation of mobile phones providing wireless Internet access have enabled real-time data recording (Fuentes et al., 2015.), which is an essential factor in Decision support systems 
Brezinščak, L. i sur.: Review of software applications for agricultural production in Croatia

(DSS) (Zheng et al., 2011.), it also allows executing agricultural tasks with just a couple of clicks, saving money and time (Delgado et al., 2014.). Use of mobile technology as explained by Dethier and Effenberger (2012.) can provide improved agricultural information at lower cost and higher quality. Other advantages of agricultural supply and demand are reducing waste, making delivery more efficient and forging closer links between farmers and consumers (Acker and, 2010). Mobile applications (apps) are defined by McNamara (2009.) as software designed to take advantage of mobile technology, developed for collection and transmission of data for economic and social activities used either for commercial, administrative or entertainment purposes. According to the literature, mobile applications are used successfully in the areas of healthcare (Ventola, 2014.), traffic monitoring (Yujuico, 2015; Khoo and Asitha 2016.), tourism (Kennedy-Eden and Gretzel, 2012.), education (Fojtik, 2015.). There is a steady rise of apps currently on the market for the agricultural sector as well as ones being developed right now (Lomotey et al., 2013.). Some examples of agricultural apps presently on Android and iOs markets: for inspecting agricultural plots used for receiving subsidies (Mesas-Carrascosa et al., 2012.), optimization of fertilization while taking into account current price of fertilizer (Bueno Delgado et al., 2016.), methods for LAI estimation (Confalonieri et al., 2013.), biomass identification via texture classification (Ionescu et al, 2015.), determining extraterrestrial solar radiation, equivalent evaporation and other parameters related to solar position (Molina-Martínez et al., 2011.), irrigation scheduling tool (Bartlett et al., 2015.). The studies mentioned show how different sectors can benefit from mobile services in different ways, given their diversity of needs and conditions. This paper aims to review software apps for agriculture production in Croatia and to introduce farmers and agricultural experts to a new way of solving specific tasks by using mobile devices.

Karetsos, Costopoulou \& Sideridis (2014.) outlined the different groups of agriculture-related applications:

Agriculture/Farm Management Information Apps

Agriculture Information Resource Apps

Agriculture Calculator Apps

Agriculture News Apps

Weather Apps

M-government Apps 
Brezinščak, L. i sur.: Review of software applications for agricultural production in Croatia

Due to the specialty of this type of apps which are currently on the Croatian market, in this paper we will cover three groups of apps.

\section{AGRICULTURE/FARM MANAGEMENT INFORMATION APPS}

Applications that are included in this category are in a great deal mobile extension of an operational management system or a farm. For example, farmers can decide what varieties and other information sources are needed before planting starts. For keeping a record of growing crops, it is possible to create electronic maps (fertilizing, planting, harvesting). The location of objects can be saved (e.g., soil sampling for agrochemical laboratory) along with notes made in the fields (e.g., warehouses, gas stations), also preserving information on operations for each field. Professionals in the green industry and homeowners can have access to pictures, information, and recommendations for managing weeds, diseases, and pests. Ranchers and grassland managers can keep records of grazing use and range and pasture conditions. Farmers can access timely, accurate data for every one of the climate monitoring stations or irrigation sets in their fields. (Karetsos et al., 2014.)

\section{Agrivi (Agrivi, 2013)}

Agrivi is a global ag-tech company developed in 2013. with a vision to change the way food is produced, positively impacting over 1 billion lives. They strive to build knowledge-based farm management solutions that address various stakeholders of the agricultural industry - farmers of all sizes, agricultural cooperatives, food sourcing industry, financial industry, NGOs, governments and all other parties interested in achieving sustainable and resource-efficient agricultural production in their network of farmers. Thousands of farmers from more than 150 countries worldwide have recognized Agrivi and are using it to manage and improve their crop production. Agrivi mobile application lets farmers get fast insight into their farming activities and register critical activities right from the field. It is used as an extension and supporting feature to fully featured web farm management solution. New mobile application users should set up their farms by a web application to get insight into their farming. Software helps farmers to control their plantations, improve productivity and increase profitability. Agrivi guides farmers to improve their production and increase productivity. There are currently offered five different products: Farm management (small and medium farms, fruit, 
Brezinščak, L. i sur.: Review of software applications for agricultural production in Croatia

vegetable and grain production, crop production, track sales \& expenses, weather monitoring \& pest alarms, reports \& analyses); Wine management (professional wine makers, vineyard \& wine cellar management, reduce risk of pests \& diseases, track activities from vineyard to bottle, measure all crucial factors, ensure wine production traceability); Enterprise farm management (enterprise solution for large growers, support for any crop production, tailormade to fit customer's needs, machinery $\&$ sensors integrations, $3^{\text {rd }}$ party integrations (ERP, CRM, etc.), private \& secured cloud, dedicated account manager); Cooperative management (managing agricultural cooperatives, farmer registry per location and crop). All of the products mentioned beforehand are provided with Traceability Report for showcasing your production and with unique QR code.

Agrivi is charged on a monthly or annual basis by purchasing a product subscription. There is a 30-day trial period in which you can try the product and get familiar with its features and benefits. After 30-days trial, you can decide to purchase a subscription or stay on a limited free plan. When purchasing any subscription, traceability report is included. There are several models: Standard (S), Professional (P) and Premium (Pre). For Farm management prices are: $\mathrm{S}$ is $12.5 €, \mathrm{P}$ is $29.5 €$, and Pre is $62.5 €$ on a monthly basis. Wine management prices are as follows $S 9 €, P 17 €$ and Pre $42 €$ monthly and depending on the production (50.000-500.000 L). Prices for Enterprise management and Cooperative management are available on demand.

\section{Farmeron (Farmeron, 2017)}

Farmeron - cloud-based, a big data system for the management of a dairy farm. Founder Matija Kopić got an idea, while observing his family struggle with a bunch of documents required for having a dairy farm: as an educated softwear developer he created app that can help his and many other families in agricultural production. Farmeron collects large amounts of information about animals in the system (nutrition, health, reproduction, milk production, medicines, etc.). Analysis of these data helps the farmer to bring the proper decision. Due to the complexity of big data, reacting in real time can be incredibly valuable and timely identification of trends can prove to be the difference between success and failure. Farmeron offers several features for finding what is the best for your farm. Event recording is one of them as marking significant changes in animals life can become costly in your time, money and materials. With this feature, it is easy to track calf management, 
Brezinščak, L. i sur.: Review of software applications for agricultural production in Croatia

health, fertility, culling if needed and create virtual holding pens. For accelerating decision-making process, Farmeron offers Dynamic reports. By analyzing data farmers can improve their business and optimize costs. Tracking Feeding, as one of the biggest single expense on a dairy farm, is smooth with Farmeron. The software provides information about feed costs, material receipts from deliveries and feeding performance. Also of great importance is knowing immediately where you stand on inventory balance, usages, and expenses, which leads to final feature Material cost \& inventory.

The Farmeron mobile app is a convenient tool that gives you access to your dairy farm records on the go, helping you to plan your workday, record daily activities and access production information wherever you are.

Pricing is available on demand.

\section{AGRICULTURE INFORMATION RESOURCE APPS}

This category includes apps that are first and foremost utilized as a lookup implements or a tool which assists in the identification of species, reviews regulations and takes expertise on a subject. For example farmers, agricultural students and any other interested in agriculture can get information in several categories such as farmer information, general information, fertilizers and pesticides prices, etc. (Karetsos et al., 2014.)

Pinova (Pinova, 2010)

Pinova d.o.o. is a company founded in 2010. in Čakovec, Croatia by individuals with many years of experience in agriculture, with the aim of creating and developing new technologies in agriculture, which will positively impacton the lives of farmers. Their projects are related to the different types of agricultural production such as pomology, viticulture, and enology, vegetable growing and field crop production.

PinovaDoc is intended for complete management and supervision of agricultural production. The application is made around the central idea of making production management more manageable for the producers. It means that records of plantations or crops that are being grown on the parcels depending on the kind (pomiculture, farming, viticulture, winemaking, vegetable growing) and model (conventional, integrated, organic) of production are all in one place and can be accessed easily at any given time. It allows you 
Brezinščak, L. i sur.: Review of software applications for agricultural production in Croatia

to collect all the data in one place and have them clear for viewing and safely stored. You can easily print out any document that you need be it records for plant protection usage or the current state of your warehouse and storage.

The app is divided into six categories. Within those six main categories, the input of data is possible through multiple subcategories.

- Input of ARKOD parcels and cadastral parcels

- Input of plantation or crop that is currently on the parcel

- Input of all agrotechnical measures and operations

- Input of all enological methods

- Input of wine production technology

- Input of soil and wine analysis

- Basic bookkeeping/accounting

- Printing all of the forms, reports, and declarations demanded by law

- Insight into storage inventory

They provide free testing of the application. For further inquiries and pricing, contact via e-mail or telephone is possible.

eGAP (egap, 2017)

eGAP application is a product of knowledge and experience of local agronomists and IT experts who are able to incorporate solutions for the needs of individual farmers and organized groups (cooperation, clusters) in order to increase production transparency, meeting the statutory regulations for keeping records and creating quality platform for a variety of certification of production and product (Integrated production, GlobalGAP, Organic agriculture). The application is implemented in the form of an Internet project and is available 24 hours a day, seven days a week on the domain egap.hr. It is important to point out, that web application technical requirements are almost non-existent, only relatively high-speed internet access and an updated browser are requires (IE, Firefox, Chrome, Safari, Opera). Use of backend databases allows fast and accurate data entry and high-quality reports on each production detail. There are four databases in the system; the first database is in the area of plant protection, it has combined information from „Agronomski glasnik" and annual publication of 'Pregled svih dozvoljenih sredstava za zaštitu bilja registriranih u RH'; the second is the Croatian variety list of fruits, vegetables, vines, cereals, sugar 
Brezinščak, L. i sur.: Review of software applications for agricultural production in Croatia

beet, fodder plants and oil and fiber plant according to the records of the seed and seedlings (HCPHS). The base includes a catalog of plant species and the associated assortment supplemented with relevant information from significant domestic authors; the third are records of fertilizers and amendments with technical information and descriptions of manufacturers in procedure to improve the soil, covering more than $95 \%$ fertilizers used in Croatia; and lastly the database that categorizes machines available on the market, providing fastest information on some of the tractors specified by the manufacturer, its primary purpose, and technical characteristics.

There are four different types of licenses available:

PRIMARY - For smaller farms up to 10ha of arable crops and 1 ha of fruit, vegetable and vine-growing use of the application is free.

BASIC - For agricultural producers whose requirements do not exceed 50 ha and 5 ha of fruit, vegetable or vineyard crops. The monthly cost of the license: $45 \mathrm{kn}$

ADVANCED - For agricultural producers whose requirements exceed BASIC license. The monthly license price: $90 \mathrm{kn}$

PRO - For large farmers whose requirements go beyond the advanced license. The monthly license price: $180 \mathrm{kn}$

Plodored (Savjetodavna, 2014)

Crop rotation - records of crop production with control of integrated production, is the application for the farmers involved in the system of integrated production which allow: proper planning of crop production, keeping records and checking all the activities and actions that have been made on farms with in the purpose of professional supervision of integrated production.This solution allows planning, recording, and supervision of integrated production in the technological process of plant production (crop production, vegetable growing, fruit growing and viticulture) according to the principles of integrated production at ARKOD plots farms. It is free of charge, you must register with your $\mathrm{MIBPG}^{1}$, and you can use it.

\footnotetext{
${ }^{1}$ Jedinstveni matični identifikacijski broj poljoprivrednog gospodarstva
} 
Brezinščak, L. i sur.: Review of software applications for agricultural production in Croatia

\section{AGRICULTURAL CALCULATOR APPS}

This app helps to make in field calculations without having to head back to the home office while using just your smartphone. (Karetsos et al., 2014)

Agricultural calculator (VVStat, 2013)

Calculators that will be mentioned further in the paper are all trademarked by prof. V. Vukadinović from Faculty of Agriculture in Osijek and are free for use. There are ten different online calculators, that will be briefly explained.

$A L R$ - cereal crops calculator is used for calculating optimal fertilization of the most important crops. The analysis is based on results from AL-method, and also supplementary information such as the types and quantities of crop residues, the application of manure, agroecological area and texture of soils. The result of calculations is the amount of nutrients needed for expected yield, lessened for the amount of bioavailable nutrient from mineralization process of organic manure, crop residues, organic matter in the soil and converted in the fertilization dose.

$A L V$ - vineyard calculator used for calculation of fertilizing dosage for the vineyard (not suitable for table grapes) obtained by AL-method and $\mathrm{pH}$ of the soil, humus concentration and mechanical composition of the soil. When setting new vineyard, it is recommended to use 3 to 5 times the amount of PK fertilizer (in proportion to the depth of plowing and depth of soil). The result is the amount of active ingredients, minus the amount of available nutrients from natural reserves of the soil and manure (only for the first year after the introduction of manure).

Nmin calculators (wheat, barley, spring crops) Nmin method is used to determine the amount of mineral forms of nitrogen (available N), before sowing for spring crops and before tillering and stem elongation of winter cereals, because the amount of mineral nitrogen is determined by the previous crop (fertilization, residual $\mathrm{N}$, and crop residue), soil and climatic conditions. Therefore, instead of individual screening, Nmin is the synthesis method of coupling all of the nitrogen availability. Even better results are obtained when nitrogen needs of the crop (network experiments, the expected yield, the number of plants $\left./ \mathrm{m}^{2}\right)$, the nitrate schedule profile, the efficiency of use of $\mathrm{N}(\mathrm{N}$ discharged / $\mathrm{N} \min <=90 \%$ ) are known.

Nmin calculators are suitable for N-top dressing and N-starter fertilization of winter cereals, corn and sugar beet with each there are short instructions. 
Brezinščak, L. i sur.: Review of software applications for agricultural production in Croatia

The potential N-mineralization is intended for the calculation of the potential rate of $\mathrm{N}$-mineralization of soil organic matter (including organic fertilizers and crop residues) which allows assessment of available nitrogen from organic reserves in soil, the resulting value should be used for the rationalization of $\mathrm{N}$-fertilizers which will provide high and stable yield with acceptable environmental loading.

Liming and sulphation are used for budget purposes of liming. The method is combined empirical-exact, which takes into account the saturation of the adsorption complex bases (BS\%), the $\mathrm{pH}$ in $\mathrm{KCl}$, hydrolytic acidity, bulk density of soil $\left(\mathrm{g}^{*} \mathrm{~cm}^{-3}\right)$ and the depth of the plow layer to $30 \mathrm{~cm}$.

NPK formulation is a simple calculator that allows you to change the recommended formulation of complex fertilizers for the one you have available by checking how much your choice is with in the needs of the crop and the soil fertility.

Optimization of fertilization is simple by a very powerful PC Excel application, which chooses the individual fertilizers by their cost and the desired formulation. The application is to be stored on PC or tablet and on Excel Solver. (Excel Add-ins, Solver)

Nitrates Directive calculator for calculating the minimal size of agricultural land and organic manure tank (compliant with Action Program ${ }^{2}$ ).

Conversion of plant nutrients is a simple calculator to convert chemical elements (e.g., P) to a chemical compound (e.g., $\mathrm{P}_{2} \mathrm{O}_{5}$ ). You can enter the amount (or concentration) of an element for plant nutrition or the amount of active substance (fertilizer) and press the "Tab" or "Enter" to convert. The calculator is bi-directional and performs conversion of plant nutrient elements to the active substance and vice versa. The application uses a decimal point.

$N$ - crop needs is a simple calculator that calculates the total need for nitrogen to achieve limited (normalized) yield, based on the crop need per yield unit, concentration of humus in the ground and $\mathrm{NO}_{3}-\mathrm{N}$. The calculator is to be used only when chemical analysis of the soil has not been preformed, a especialy Nmin method for determining the needs of crops in nitrogen. The recommended total dose of nitrogen is orientational and is substantially a less reliable application than ALR calculator and chemical analysis of the soil.

\footnotetext{
${ }^{2}$ Zaštite voda od onečišćenja uzrokovanog nitratima poljoprivrednog podrijetla (NN 15/2013)
} 
Brezinščak, L. i sur.: Review of software applications for agricultural production in Croatia

\section{CONCLUSION}

The information and communication technologies are increasing worldwide. According to Fischer et al. (2009), ICT has a great potential and should be given the same importance as the biotechnological revolution. Agricultural production is one of the few big areas left without enough new facilities to increase their income and produce. Lack of implementing new technologies places agriculture in a low positions in search of opportunities for on-farm efficiency, information gathering and associating with people that are fundamental to the agro-business. As businesses are becoming more technologically advanced, citizens or in this case farmers are getting more and more acquainted with smartphones. But still, the gap between all participants in the production chain is too wide. Internet speed and phone reception in rural areas which are very low or non-existent are not helping at all. It is important that government and telecom companies together address this problem. Capabilities that are related to a smartphone, such as ease of access and extended reach of information are widely recognized. Nonetheless, according to literature, use of smartphone apps is still in its infancy. As presented in this paper only a few apps exist in Croatian market that are interactive and helpful for farm management. Finding information and submitting applications in a user-friendly and simple way, is a great benefit when using apps. Also making timely decisions can prove to be of great significance, ultimately leading to better yields. Any way to save time and money for farmers is always welcome, especially when bureaucracy is involved. So, considering a smartphone as a working tool should be interesting for farmers. The objective of using smartphone apps is to achieve growth by reducing the gap between small and large farmers by sharing of knowledge and information. More research is needed to improve and fully understand their usability and potential for sustainability.

Use of all mentioned calculators and apps is only for the provisional purpose and can not replace laboratory analysis and recommendation from agricultural experts. 
Brezinščak, L. i sur.: Review of software applications for agricultural production in Croatia

\section{REFERENCES}

1. Agrivi (2013.): Agrivi d.o.o., Agrivi website [online] Available at: http://www.agrivi.com [Accessed 5 March 2017]

2. Aker, J. C., Mbiti, I. M. (2010.): Mobile phones and economic development in Africa. The Journal of Economic Perspectives, 24(3), 207-232.

3. Bartlett, A. C., Andales, A. A., Arabi, M., Bauder, T. A. (2015.): A smartphone app to extend use of a cloud-based irrigation scheduling tool. Computers and Electronics in Agriculture, 111, 127-130.

4. Bueno-Delgado, M. V., Molina-Martínez, J. M., Correoso-Campillo, R., Pavón-Mariño, P. (2016.): Ecofert: An Android application for the optimization of fertilizer cost in fertigation. Computers and Electronics in Agriculture, 121, 32-42.

5. Confalonieri, R., Foi, M., Casa, R., Aquaro, S., Tona, E., Peterle, M., ... \& Guarneri, T. (2013.): Development of an app for estimating leaf area index using a smartphone. Trueness and precision determination and comparison with other indirect methods. Computers and Electronics in Agriculture, 96, 67-74.

6. Croatian Bureau of Statistics (2015.): Annual report for 2015, [online] Zagreb. Available at: http://www.dzs.hr/Hrv_Eng/ljetopis/2015/sljh2015.pdf [Accessed 5 March 2017]

7. Delgado, B., Paredes, M., Martínez, M. (2015.): Software application for calculating solar radiation and equivalent evaporation in mobile devices. Agricultural Water Management, 151, 30-36.

8. Dethier, J.-J., Effenberger, A. (2012.): Agriculture and development: A brief review of the literature. Econ. Syst.

9. eGap (2017.): eGap website, [online] Available at: http://www.egap.hr/modelikoristenja/ [Accessed 5 March 2017]

10. Efken, J. (1998.): Computer - based networks - Perspectives for agriculture Considerations about the possible future role of Internet or similar computer based networks for farmers. Landbauforschung Volkenrode, 48, (3), 159-167.

11. Farmeron (2017.): Farmeron website[online] Available at: http://www.farmeron.com/ [Accessed 1 March 2017]

12. Fischer R.A., Byerlee, D., Edmeades, G.O. (2009.): Can Technology Deliver on the Yield Challenge to 2050? Prepared for UN \& FAO Expert Meeting on How to feed the World in 2050, (Rome, 24-26 June 2009) 
Brezinščak, L. i sur.: Review of software applications for agricultural production in Croatia

13. Fuentelsaz, L., Maícas, J. P., Polo, Y. (2008.): The evolution of mobile communications in Europe: The transition from the second to the third generation. Telecommunications Policy, 32(6), 436-449.

14. Fojtik, R. (2015.): Ebooks and mobile devices in education. Procedia-Social and Behavioral Sciences, 182, 742-745.

15. Fountas, S., Carli, G., Sørensen, C. G., Tsiropoulos, Z., Cavalaris, C., Vatsanidou, A., Liakos, B., Canavari, M., Wiebensohn, J., Tisserye, B. (2015.): Farm management information systems: Current situation and future perspectives. Computers and Electronics in Agriculture, 115, 40-50.

16. Ionescu, R. T., Popescu, A. L., Popescu, M., Popescu, D. (2015.): BiomassID: a biomass type identification system for mobile devices. Computers and Electronics in Agriculture, 113, 244-253.

17. Kennedy-Eden, H. \& Gretzel, U. (2012.): A taxonomy of mobile applications in tourism. E-review of Tourism Research, 10 (2), 47-50.

18. Khoo, H. L., \& Asitha, K. S. (2016.): User requirements and route choice response to smart phone traffic applications (apps). Travel Behaviour and Society, 3, 59-70.

19. Lomotey, R. K., Chai, Y., Jamal, S., Deters, R. (2013.): Mobicrop: Supporting crop farmers with a cloud-enabled mobile app. In Service-Oriented Computing and Applications (SOCA), 2013 IEEE 6th International Conference on (pp. 182-189). IEEE.

20. Ljubaj, T., Franić, R., Njavro, M. (2012.): Socioekonomske promjene u ruralnom podrucju istarske županije. Agronomski glasnik, 74(1), 31-50.

21. Mesas-Carrascosa, F. J., Castillejo-González, I. L., De La Orden, M. S., García-Ferrer, A. (2012.): Real-time mobile phone application to support land policy. Computers and electronics in agriculture, 85, 109-111.

22. McNamara, K. (2009.): Mobile Applications in Agriculture and Rural Development: Framing the Topic, and Learning from Experience.

World Bank, Washington, D.C.

http://siteresources.worldbank.org/EXTEDEVELOPMENT/Resources/Slides

McNamara_revised.pptx.

23. Molina-Martínez, J. M., Jiménez, M., Ruiz-Canales, A., Fernández-Pacheco, D. G. (2011.): RaGPS: A software application for determining extraterrestrial radiation in mobile devices with GPS. Computers and electronics in agriculture, 78(1), 116-121. 
Brezinščak, L. i sur.: Review of software applications for agricultural production in Croatia

24. Pinova (2010.): Pinova d.o.o., Pinova website [online] Available at: http://pinova.hr/hr_HR/pinova/nasi-proizvodi-i-usluge/pinovadoc-internet-imobilna-aplikacija-za-evidencije-u-agrarnoj-proizvodnji\# [Accessed 5 March 2017].

25. Qiang, C. Z., Kuek, S. C., Dymond, A., Esselaar, S., Unit, I. S. (2011.): Mobile applications for agriculture and rural development. World Bank, Washington, DC.

26. Savjetodavna.hr (2014.): Plodored website [online] Available at: http://plodored.savjetodavna.hr/app/login.php [Accessed 5 March 2017].

27. Šundalić, A., Mesarić, J., Pavić, Ž. (2010.): Suvremeni seljak i informacijska tehnologija. Informatol. 43 (3) 219-227.

28. Ventola, C. L. (2014.): Mobile devices and apps for health care professionals: uses and benefits. PT, 39(5), 356-364.

29. VVStat (2013.): Statistical package [online] Poljoprivredni fakultet u Osijeku, Zavod za kemiju, biologiju i fiziku tla, prof.dr.sc. V.Vukadinovic. Available at: http://ishranabilja.com.hr/kalkulatori.html [Accessed 8 March 2017].

30. World Bank (2012.): Scientific and Technical Journal Articles. [online]

31. Yujuico, E. (2015.): Considerations in the diffusion of a public traffic app for Metro Manila. Journal of Transport Geography, 42, 48-56.

32. Zheng, L., Li, M., Wu, C., Ye, H., Ji, R., Deng, X., Che, Y., Fu, C., Guo, W. (2011.): Development of a smart mobile farming service system. Mathematical and computer modelling 54, 1194-1203.

\section{Author's address - Adresa autora:}

Luka Brezinščak, mag. ing. agr., corresponding author e-mail: 1brezinscak@agr.hr prof.dr.sc. Milan Mesić, e-mail: mmesic@agr.hr

Faculty of Agriculture University of Zagreb, Svetošimunska cesta 25 , 10000 Zagreb, Croatia

\section{Received - Primljeno}

19.02.2018. 